\title{
PERLAKUAN PERENDAMAN DALAM LARUTAN ASAM UNTUK MENGHAMBAT PERKEMBANGAN HISTAMIN PADA PINDANG IKAN LISONG (Scomber australasicus CV)
}

\author{
Dwiyitno"), Farida Ariyani"), Teti Kusmiyati") dan Harmita"*)
}

\begin{abstract}
ABSTRAK
Penelitian ini dilakukan untuk melihat pengaruh perlakuan perendaman dalam larutan asam (sitrat dan laktat) pada ikan sebelum dilakukan pemindangan terhadap kandungan histamin pindang ikan lisong (Scomber australasicus CV). Pada penelitian ini ikan direndam dalam larutan asam sitrat dan asam laktat pada $\mathrm{pH} 4$ dengan variasi lama perendaman 15, 30 dan 45 menit. Selanjutnya ikan dipindang dalam larutan garam 15\% selama 30 menit. Parameter yang diamati meliputi kadar air, histamin, jumlah bakteri pembentuk histamin, total volatile base (TVB) dan organoleptik. Perendaman dalam larutan asam baik sitrat maupun laktat berpengaruh nyata terhadap kandungan histamin, jumlah bakteri pembentuk histamin dan TVB tetapi tidak berpengaruh nyata terhadap kadar air, pH ikan serta nilai organoleptik. Waktu perendaman berpengaruh nyata terhadap parameter yang diamati yaitu semakin lama waktu perendaman, kandungan histamin, jumlah bakteri pembentuk histamin dan TVB ikan pindang semakin rendah.
\end{abstract}

\section{ABSTRACT: Soaking treatment in acids solution to retard histamine development on boiled slimy mackerel (Scomber australasicus CV). By: Dwiyitno, Farida Ariyani, Teti Kusmiyati, and Harmita}

\begin{abstract}
A research was conducted to evaluate the effect of soaking treatment in acids solution (lactic and citric acids) before boiling on the histamine content of Scomber australasicus CV boiled fish. In the experiment, fish were soaked in citric or lactic acids solution at pH 4 for 15, 30, and 45 minutes, and then boiled in $15 \%$ salt solution for 30 minutes. Histamine, moisture, total volatile base (TVB) contents and the number of histamine forming bacteria as well as organoleptic quality were determined. Soaking in either acids solution gave significant effect on histamine content, the number of histamine forming bacteria and TVB content, but insignificant on moisture, $\mathrm{pH}$, and organoleptic score of boiled fish. Time of soaking significantly influenced the extent of quality; the longer the soaking time, the lower the number of histamine forming bacteria, histamine and TVB contents.
\end{abstract}

KEYWORDS: Scomber australasicus CV, lactic acid, citric acid, histamine, histamine forming bacteria, total volatile base

\section{PENDAHULUAN}

Kasus keracunan produk perikanan masih sering terjadi di Indonesia. Keracunan akibat mengkonsumsi produk perikanan dapat disebabkan oleh ikan/produk perikanan yang secara alami memang memiliki kandungan racun seperti ikan buntal. Di samping itu keracunan juga dapat disebabkan karena mengkonsumsi ikan/produk perikanan yang telah terkontaminasi baik oleh mikroba maupun oleh toksin tertentu seperti saksitoksin dan histamin. Dari beberapa kasus keracunan, keracunan histamin merupakan penyebab yang paling sering terjadi (Supraptini, 1998).
Histamin merupakan suatu senyawa biogenik amin yang terbentuk oleh proses dekarboksilasi asam amino histidin, terutama histidin bebas. Proses dekarboksilasi ini dipicu oleh enzim histidin dekarbosilase yang dihasilkan oleh beberapa jenis bakteri dan menghasilkan senyawa baru yang bersifat toksik yaitu histamin. Kandungan histamin di atas $100 \mathrm{mg} / 100 \mathrm{~g}$ pada suatu produk umumnya dapat menyebabkan terjadinya keracunan apabila dikonsumsi (Wonggo, 1995). Pada ikan yang benarbenar segar, kandungan histamin bisa kurang dari 10 $\mathrm{mg} / 100 \mathrm{~g}$ (Ozogul et al., 2004). Gejala keracunan histamin adalah gatal-gatal, diare, demam, sakit kepala dan tekanan darah turun (Taylor, 1986). 
Kandungan histamin banyak ditemukan pada ikanikan famili skombroid, sehingga racun histamin juga dikenal dengan istilah skombrotoksin. Pada umumnya daging ikan mengandung asam amino histidin, yang banyak ditemukan pada bagian daging merah (Haaland et al., 1990). Ikan-ikan jenis skombroid seperti, tuna, cakalang dan tongkol umumnya memiliki kandungan daging merah lebih banyak dari pada ikan jenis lain (Ababouch et al., 1992).

Proses pembentukan histamin pada ikan sangat dipengaruhi oleh kondisi lingkungan. Pembentukan histamin hampir terhenti pada suhu $5^{\circ} \mathrm{C}$, sedangkan pada suhu $0^{\circ} \mathrm{C}$ terhenti sama sekali. Suhu optimum bagi pertumbuhan bakteri pembentuk histamin adalah $20-25^{\circ} \mathrm{C}$ dengan $\mathrm{pH}$ sekitar $6-7$ dengan jenis bakteri yang dominan adalah Proteus morganii, Hafnia alvei, Klebsiella pneumonia dan Clostridium perfringens (Rawles et al., 1996). Dengan demikian manipulasi salah satu atau kedua faktor lingkungan (suhu dan $\mathrm{pH}$ ) di atas diharapkan dapat menghambat pertumbuhan bakteri pembentuk histamin sehingga proses produksi histamin pun juga menjadi terhambat. Perlakuan perendaman dengan larutan asam laktat $(1,5-6 \%)$ untuk menghambat pertumbuhan bakteri pada penyimpanan ikan dan udang pernah dilakukan oleh Den Uijl (1989).

Keracunan histamin sering terjadi akibat mengkonsumsi produk olahan tradisional seperti pindang ikan. Hal ini karena ikan-ikan hasil tangkapan yang tidak memenuhi syarat dan kurang segar ternyata masih diolah dan dikonsumsi (Kongpun \& Suwonsakornkul, 2000). Sementara itu hasil penelitian Heruwati et al. (2003) menunjukkan kandungan histamin ikan cakalang segar dan pindang tongkol dari Pelabuhan Ratu masing-masing 234,41 $\mathrm{mg} / 100 \mathrm{~g}$ dan $247,58-298,04 \mathrm{mg} / 100 \mathrm{~g}$, ikan peda dari Batang $88,83-125,39 \mathrm{mg} / 100 \mathrm{~g}$ dan ikan asin dari Jakarta $77,39 \mathrm{mg} / 100 \mathrm{~g}$.

Produk yang mengandung histamin di atas $50 \mathrm{mg} /$ $100 \mathrm{~g}$ sudah berbahaya untuk kesehatan dan level berbahaya untuk kesehatan adalah di atas $100 \mathrm{mg} /$ $100 \mathrm{~g}$ (SNI 01-2360, 1991). Dengan demikian peluang terjadinya keracunan histamin besar, mengingat ikan pindang merupakan bentuk produk olahan yang sudah lama dikenal dan digemari oleh masyarakat Indonesia. Produk ini biasanya dibuat dari jenis ikan-ikan skombroid yang sudah rendah mutunya.

Pada penelitian ini digunakan perlakuan perendaman ikan lisong dalam larutan asam sebelum dilakukan pemindangan. Perlakuan asam dimaksudkan untuk memanipulasi/menurunkan $\mathrm{pH}$ sehingga pertumbuhan bakteri pembentuk histamin menjadi terhambat.

\section{BAHAN DAN METODE}

Jenis ikan yang digunakan adalah ikan lisong (Scomber australasicus CV) dengan bobot antara 315-375 g, panjang 26,5-31,0 cm dan lebar 7,5-9,0 $\mathrm{cm}$ yang diperoleh dari kapal one day fishing di Binuangeun, Propinsi Banten. Ikan hasil tangkapan nelayan langsung dies dalam coolbox dan dibawa ke laboratorium Pusat Riset Pengolahan Produk dan Sosial Ekonomi Kelautan dan Perikanan, Jakarta. Terhadap ikan segar dilakukan analisis kadar air, TVB, histamin, $\mathrm{pH}$ dan uji organoleptik.

Ikan dibagi menjadi dua kelompok, kelompok pertama direndam dalam larutan asam sitrat dan kelompok kedua dalam larutan asam laktat. Larutan asam yang digunakan memiliki pH 4 (Den Uijl, 1989). Perlakuan waktu perendaman yaitu 15, 30 dan 45 menit pada suhu kamar. Selanjutnya ikan direbus dalam larutan garam $15 \%$ selama 30 menit. Ikan pindang kemudian disimpan pada suhu kamar. Pengamatan dilakukan terhadap kandungan histamin, TVB, kadar air, jumlah bakteri pembentuk histamin dan nilai organoleptik, yaitu pada hari ke-0,2 dan 4. Penilaian organoleptik dilakukan terhadap mata, insang, tekstur, dinding perut, sayatan otot dan bau untuk ikan mentah serta rasa untuk ikan matang oleh 10 orang panelis terlatih dengan skala masing-masing $1-5$.

Analisis kadar histamin dilakukan menurut metode Hardy \& Smith (1976), jumlah bakteri pembentuk histamin dengan metode Anggawati et al. (1984), total volatile base (TVB) dan kadar air dengan metode standar AOAC (AOAC, 1980). Pengukuran pH dilakukan dengan alat $\mathrm{pH}$ meter merk Thermo Orion. Disain penelitian menggunakan metode rancangan acak lengkap dengan 3 kali ulangan. Terhadap data yang diperoleh dilakukan analisis sidik ragam (anova), dan Kruskal Walis untuk non parametrik. Apabila hasil anova berbeda nyata dilakukan uji lanjut Duncan Multiple Range Test (DMRT) (Steel \& Torrie, 1989).

\section{HASIL DAN BAHASAN}

Kadar air pindang ikan lisong berkisar antara 56,69 sampai $66,45 \%$ (Gambar 1). Perlakuan perendaman dalam larutan asam tidak berpengaruh nyata terhadap kadar air pindang, kecuali pada hari ke-4 penyimpanan. Semakin lama penyimpanan kadar air pindang semakin turun. Penurunan ini dikarenakan terjadi proses penguapan selama penyimpanan.

Data kandungan histamin pindang selama penyimpanan disajikan pada Gambar 2. Perlakuan perendaman, baik dalam larutan asam sitrat maupun asam laktat berpengaruh nyata terhadap kandungan histamin pindang ikan lisong. Pindang dengan bahan 


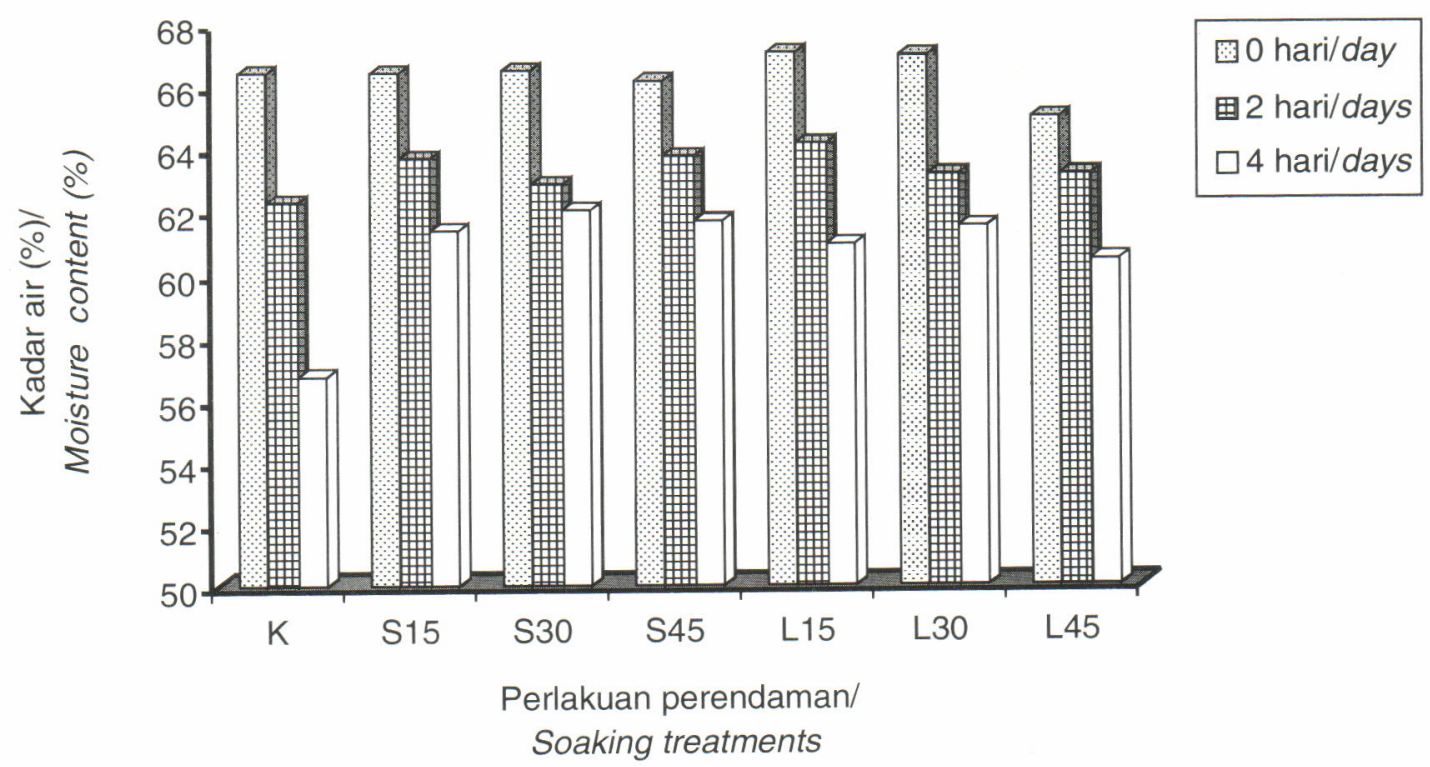

Keterangan/Note: $\mathrm{K}=\mathrm{Kontrol} /$ Control

$\mathrm{S}=$ As.Sitrat/Citric Ac. $(15,30,45 \mathrm{menit} / \mathrm{min})$

$\mathrm{L}=$ As. Laktat/Lactic Ac. $(15,30,45 \mathrm{menit} / \mathrm{min})$

Gambar 1. Kadar air pindang ikan lisong (S. australasicus CV) dari berbagai perlakuan selama penyimpanan. Figure 1. Moisture content of boiled slimy mackerel (S. australasicus CV) of various treatments during storage.

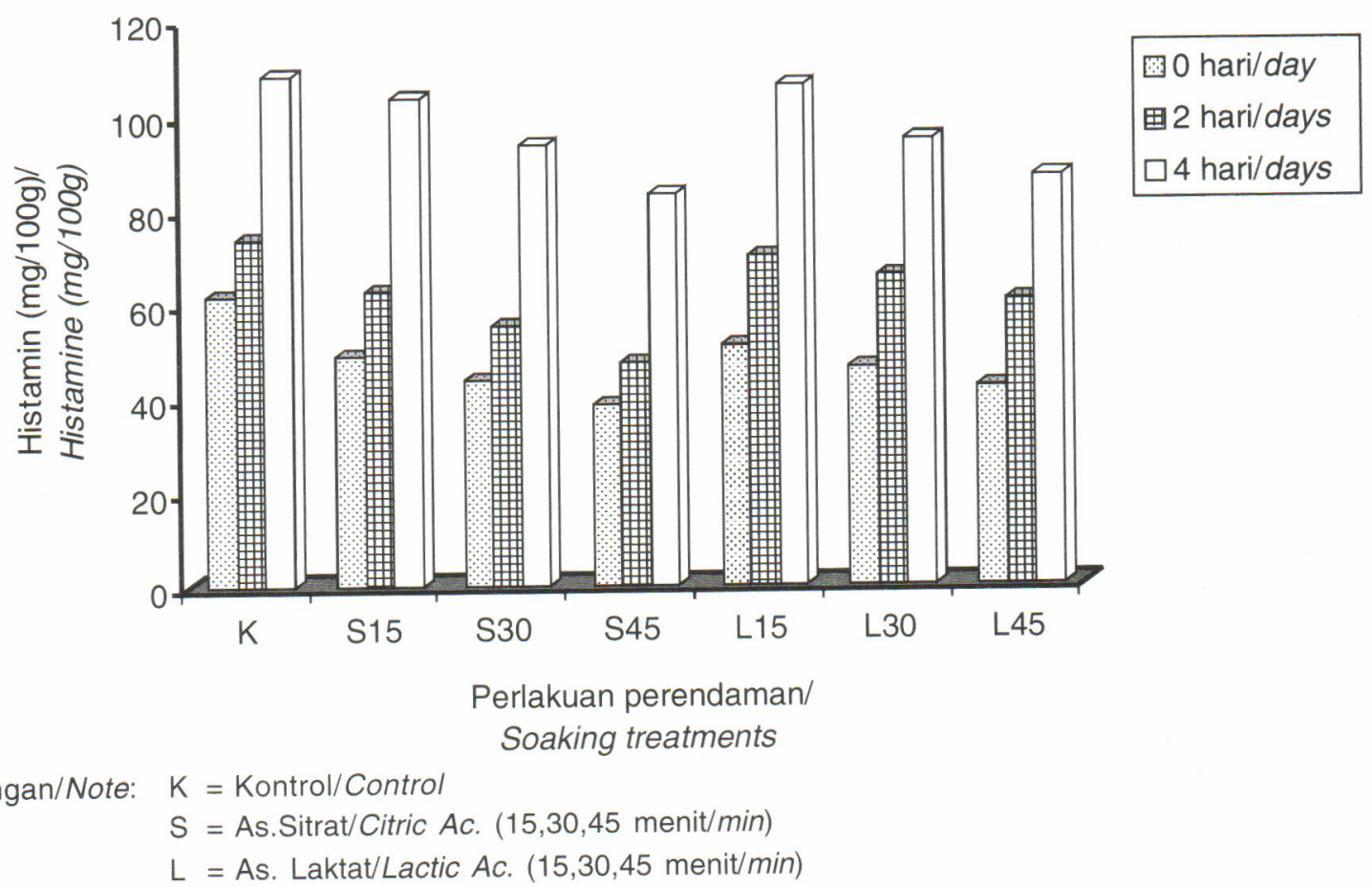

Gambar2. Pengaruh perlakuan perendaman terhadap kandungan histamin pindang ikan lisong ( $S$. australasicus $\mathrm{CV}$ ) selama penyimpanan .

Figure 2. The effect of soaking treatments on histamine content of boiled slimy mackerel(S. australasicus CV) during storage. 
baku tanpa perendaman (kontrol) sudah tidak layak untuk dikonsumsi pada hari ke-4 penyimpanan karena kandungan histaminnya mencapai di atas $100 \mathrm{mg} /$ $100 \mathrm{~g}(108,18 \mathrm{mg} / 100 \mathrm{~g})$. Sementara itu pada pindang dengan bahan baku yang direndam dalam larutan asam (sitrat dan laktat) selama 15 menit juga menunjukkan kandungan histamin di atas $100 \mathrm{mg} /$ $100 \mathrm{~g}$ pada penyimpanan hari ke-4. Akan tetapi pada perlakuan lama perendaman 30 dan 45 menit kandungan histamin pada hari ke-4 penyimpanan masih di bawah $100 \mathrm{mg} / 100 \mathrm{~g}$. Dengan demikian terdapat korelasi antara lama perendaman dengan laju pembentukan histamin, yaitu semakin lama perendaman maka kandungan histamin semakin rendah.

Proses pembentukan histamin pada ikan sangat ditentukan oleh aktivitas enzim histidin dekarboksilase yang dihasilkan oleh bakteri pembentuk histamin (Bennour et al., 1991). Pada penelitian ini perlakuan perendaman dalam larutan asam berpengaruh nyata terhadap jumlah bakteri pembentuk histamin terutama pada hari ke-0 dan ke-2 penyimpanan. Pindang dengan bahan baku yang direndam dalam asam memiliki jumlah bakteri yang lebih rendah dari perlakuan kontrol (Gambar 3). Pada hari ke-4 penyimpanan hanya pindang dengan bahan baku yang direndam larutan asam sitrat selama 45 menit yang memiliki jumlah bakteri berbeda nyata dengan kontrol. Meningkatnya jumlah bakteri pada hari ke-4 kemungkinan dikarenakan faktor lingkungan terutama suhu dan $\mathrm{pH}$ yang turut mendukung bagi pertumbuhan bakteri pembentuk histamin. Pada penelitian ini penyimpanan dilakukan pada suhu kamar dan $\mathrm{pH}$ ikan pindang hasil perlakuan sampai akhir penyimpanan ternyata masih di atas 6 (Gambar 5). Jika dikaitkan dengan kandungan histamin, jumlah bakteri pembentuk histamin berkorelasi dengan kandungan histamin pada pindang ikan selama penyimpanan.

Perlakuan perendaman bahan baku dalam larutan asam berpengaruh nyata terhadap kandungan TVB pindang ikan (Gambar 4), yaitu semakin lama perendaman kandungan TVB semakin rendah. Dengan demikian perlakuan perendaman dalam larutan asam (sitrat dan laktat) dapat menekan jumlah bakteri sehingga proses produksi senyawa-senyawa basa maupun amin yang mudah menguap (volatile) juga terhambat. Peningkatan kandungan TVB berkaitan dengan proses autolisis enzimatik serta

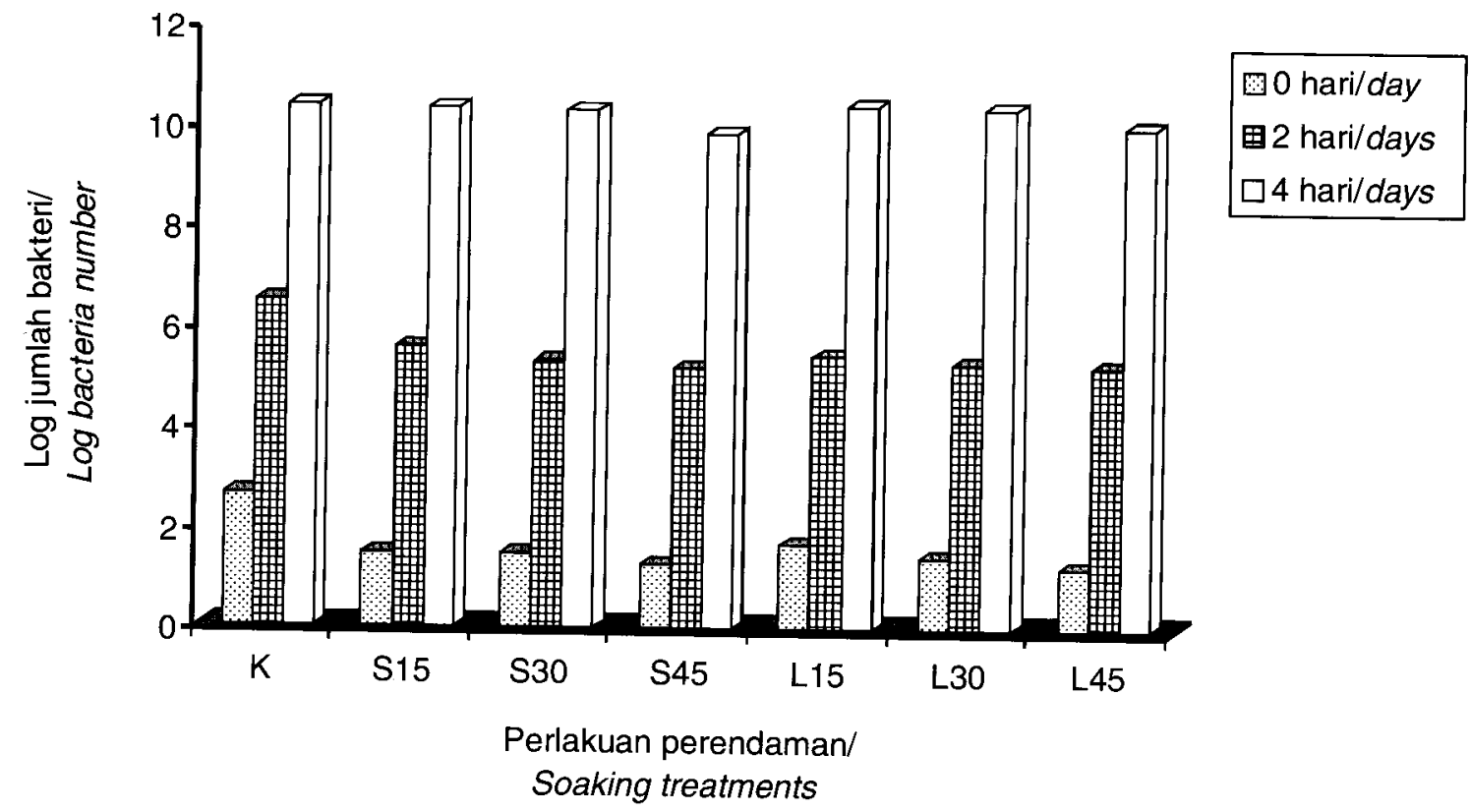

Keterangan/Note: $\mathrm{K}=\mathrm{K}$ ontrol/Control

$\mathrm{S}=$ As.Sitrat/Citric Ac. $(15,30,45 \mathrm{menit} / \mathrm{min})$

$\mathrm{L}=$ As. Laktat/Lactic Ac. (15,30,45 menit/min)

Gambar 3. Pertumbuhan bakteri pembentuk histamin pada pindang ikan lisong (S. australasicus CV) selama penyimpanan pada berbagai perlakuan.

Figure 3 Growth of histamine forming bacteria in boiled slimy mackerel (S. australasicus CV) during storage at various treatments. 


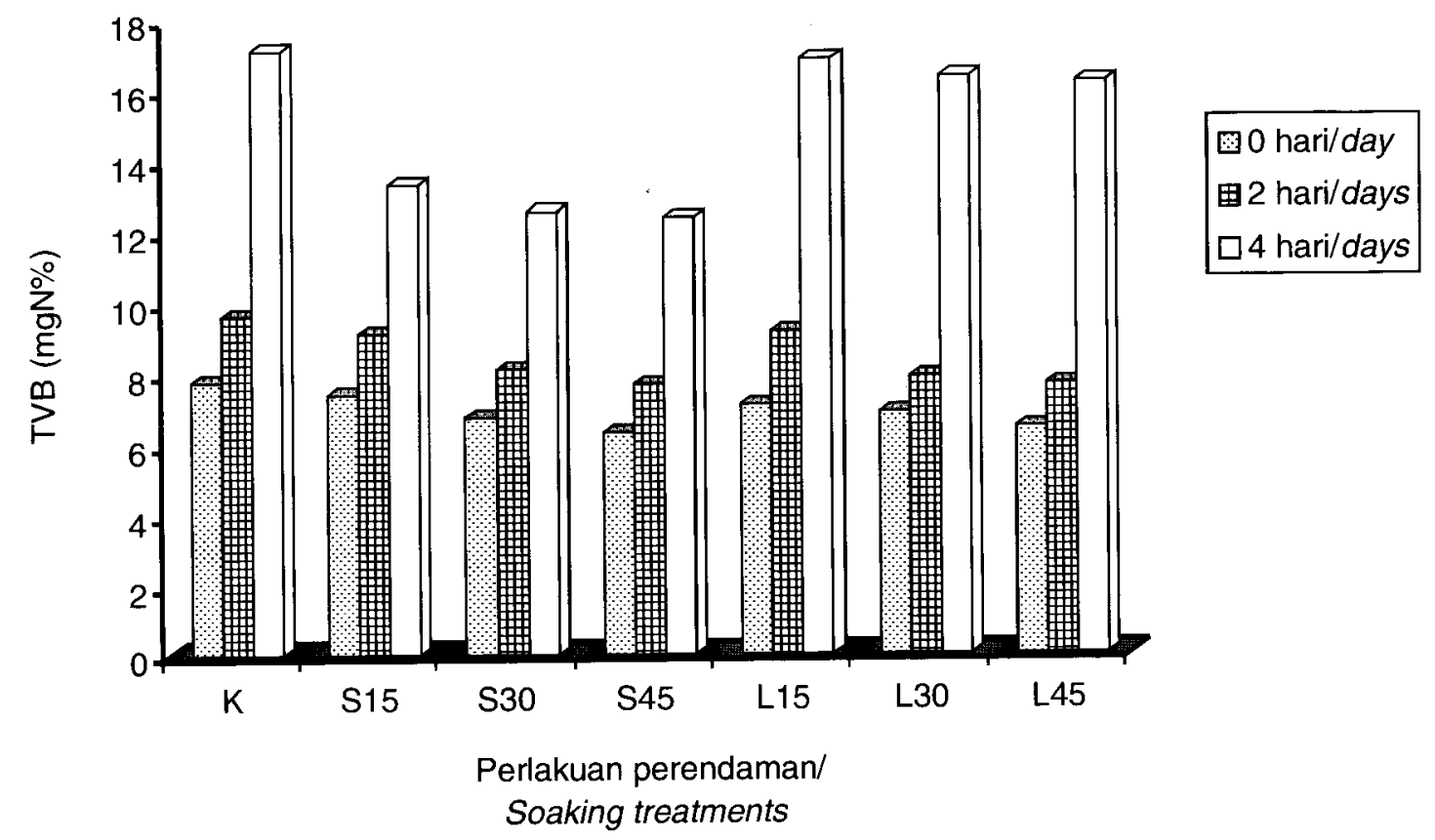

Keterangan/Note: $\mathrm{K}=$ Kontrol/Control

$\mathrm{S}=$ As.Sitrat $/$ Citric Ac. $(15,30,45 \mathrm{menit} / \mathrm{min})$

$\mathrm{L}=$ As. Laktat $/$ Lactic Ac. $(15,30,45 \mathrm{menit} / \mathrm{min})$

Gambar 4. Pengaruh perlakuan perendaman terhadap kandungan TVB pindang ikan lisong (S. australasicus CV) selama penyimpanan.

Figure 4. The effect of soaking treatments on TVB content of boiled slimy mackerel (S. australasicus CV) during storage.

aktivitas bakteri, terutama bakteri halofilik (HernandezHerrero et al., 1999). Secara umum sampai dengan hari ke-4 penyimpanan, kandungan TVB pindang masih di bawah batas persyaratan yang berlaku di banyak negara yaitu $200 \mathrm{mgN} \%$ untuk ikan olahan dengan perlakuan penggaraman (Connel, 1975). Sementara itu penelitian Beirão (1979) menunjukkan bahwa kandungan TVB pada pengolahan ikan sardin Sardinella brasiliensis sekitar $70 \mathrm{mgN} \%$. Pada penelitian ini larutan asam sitrat relatif lebih baik dalam menekan kandungan TVB bila dibandingkan dengan asam laktat.

Pengaruh perlakuan perendaman bahan baku dalam larutan asam terhadap $\mathrm{pH}$ pindang ikan lisong seperti terlihat pada Gambar 5 . Perlakuan perendaman baik dalam larutan asam sitrat maupun asam laktat $\mathrm{pH} 4$ selama 15-45 menit tidak berpengaruh nyata terhadap pH ikan pindang. Hal ini kemungkinan karena waktu perendaman yang singkat tidak memungkinkan larutan asam meresap ke dalam daging ikan, melainkan hanya di permukaan saja. Di samping itu perlakuan pemindangan setelah perendaman memungkinkan larutnya kembali larutan asam selama proses pemindangan. Hasil uji organoleptik juga menunjukkan bahwa tidak ada perbedaan nyata pada respon panelis terhadap parameter rasa.

Meskipun tidak berpengaruh nyata terhadap $\mathrm{pH}$ ikan pindang, data kandungan bakteri maupun TVB menunjukkan bahwa perlakuan perendaman ikan sebelum pemindangan berpengaruh nyata terhadap penghambatan pertumbuhan bakteri. Menurut Fardiaz (1992), pengasaman merupakan salah satu cara pengawetan makanan yang telah dilakukan sejak lama. Pada medium dengan $\mathrm{pH}$ rendah, bakteri akan bereaksi untuk mempertahankan pH konstan/optimum di dalam selnya. Pada waktu $\mathrm{pH}$ diturunkan dari $\mathrm{pH}$ optimum, proton yang terdapat dalam jumlah tinggi di dalam medium akan masuk ke dalam sitoplasma sel. Selanjutnya proton ini harus dihilangkan dari dalam sel untuk mencegah terjadinya pengasaman dan denaturasi komponen-komponen sel. Proses penghilangan proton ini memerlukan energi yang besarnya tergantung tinggi-rendahnya $\mathrm{pH}$. Akibatnya energi untuk pertumbuhan sel menjadi berkurang bahkan pertumbuhannya dapat berhenti sama sekali.

Pengaruh perlakuan perendaman bahan baku dalam larutan asam (sitrat dan laktat) terhadap total penerimaan pindang ikan oleh panelis terlihat pada 


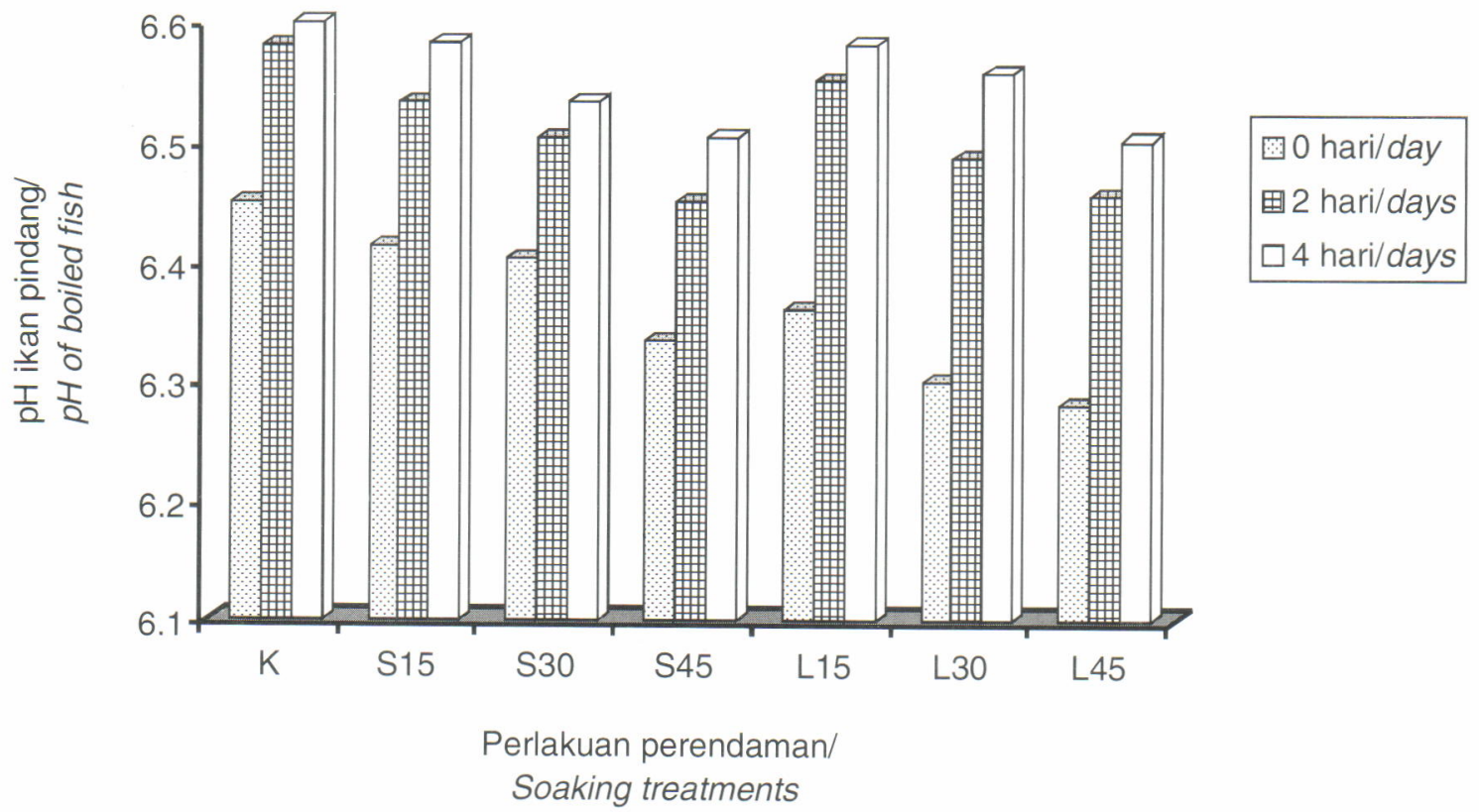

$\begin{aligned} \text { Keterangan/Note: } & \mathrm{K}=\text { Kontrol/Control } \\ & \mathrm{S}=\text { As. Sitrat } / \text { Citric Ac. }(15,30,45 \mathrm{menit} / \mathrm{min}) \\ & \mathrm{L}=\text { As. Laktat } / \text { Lactic Ac. }(15,30,45 \mathrm{menit} / \mathrm{min})\end{aligned}$

Gambar 5. Pengaruh perlakuan perendaman terhadap $\mathrm{pH}$ pindang ikan lisong ( $\mathrm{S}$. australasicus $\mathrm{CV}$ ) selama penyimpanan.

Figure 5. The effect of soaking treatments on $\mathrm{pH}$ of boiled slimy mackerel (S. australasicus $\mathrm{CV}$ ) during storage.

Gambar 6. Meskipun secara statistik tidak terlihat perbedaan yang nyata pengaruh perlakuan perendaman bahan baku dalam larutan asam, namun pindang yang bahan bakunya direndam dalam larutan asam lebih disukai panelis daripada kontrol. Hal ini karena perendaman bahan baku dalam larutan asam menghasilkan pindang dengan penampakan yang lebih bersih daripada kontrol. Sedangkan perendaman dalam larutan asam sitrat relatif menghasilkan pindang yang lebih disukai panelis daripada perendaman dalam larutan asam laktat. Hal ini karena ikan yang direndam dalam larutan asam laktat menghasilkan pindang dengan kulit yang licin. Semakin lama penyimpanan, nilai organoleptik pindang semakin menurun. Pada hari ke-2 penyimpanan, penerimaan panelis terhadap ikan pindang dari seluruh perlakuan masih baik. Panelis mulai menolak ikan pindang dari seluruh perlakuan pada hari ke-4 penyimpanan. Pada hari ke-4 ikan pindang sudah mulai ditumbuhi jamur dan permukaannya mulai berlendir.

\section{KESIMPULAN}

1. Perlakuan perendaman ikan baik dalam larutan asam sitrat maupun asam laktat mampu menekan pertumbuhan bakteri pembentuk histamin serta menghambat perkembangan pembentukan histamin dan TVB pada ikan pindangnya.

2. Berdasarkan parameter kimia dan mikrobiologi, ikan yang direndam dalam kedua jenis asam selama 30 dan 45 menit menghasilkan pindang yang masih layak untuk dikonsumsi hingga hari ke-4 pengamatan. Sedangkan pada perendaman selama 15 menit hanya tahan hingga hari ke-2 pengamatan, sama dengan perlakuan kontrol.

3. Perendaman pada $\mathrm{pH} 4$ tidak berpengaruh nyata terhadap rasa produk pindang. Hasil uji organoleptik menunjukkan pindang ikan dari seluruh perlakuan masih disukai oleh panelis. Untuk parameter penampakan, panelis lebih menyukai pindang yang direndam kedua jenis asam dari pada kontrol. Sementara perlakuan perendaman dalam larutan asam sitrat menghasilkan pindang yang lebih disukai panelis dibandingkan dengan yang direndam dalam larutan asam laktat.

4. Perendaman dalam larutan asam sitrat $\mathrm{pH} 4$ selama 45 menit disarankan untuk dilakukan selama ikan menunggu proses pengolahan. 


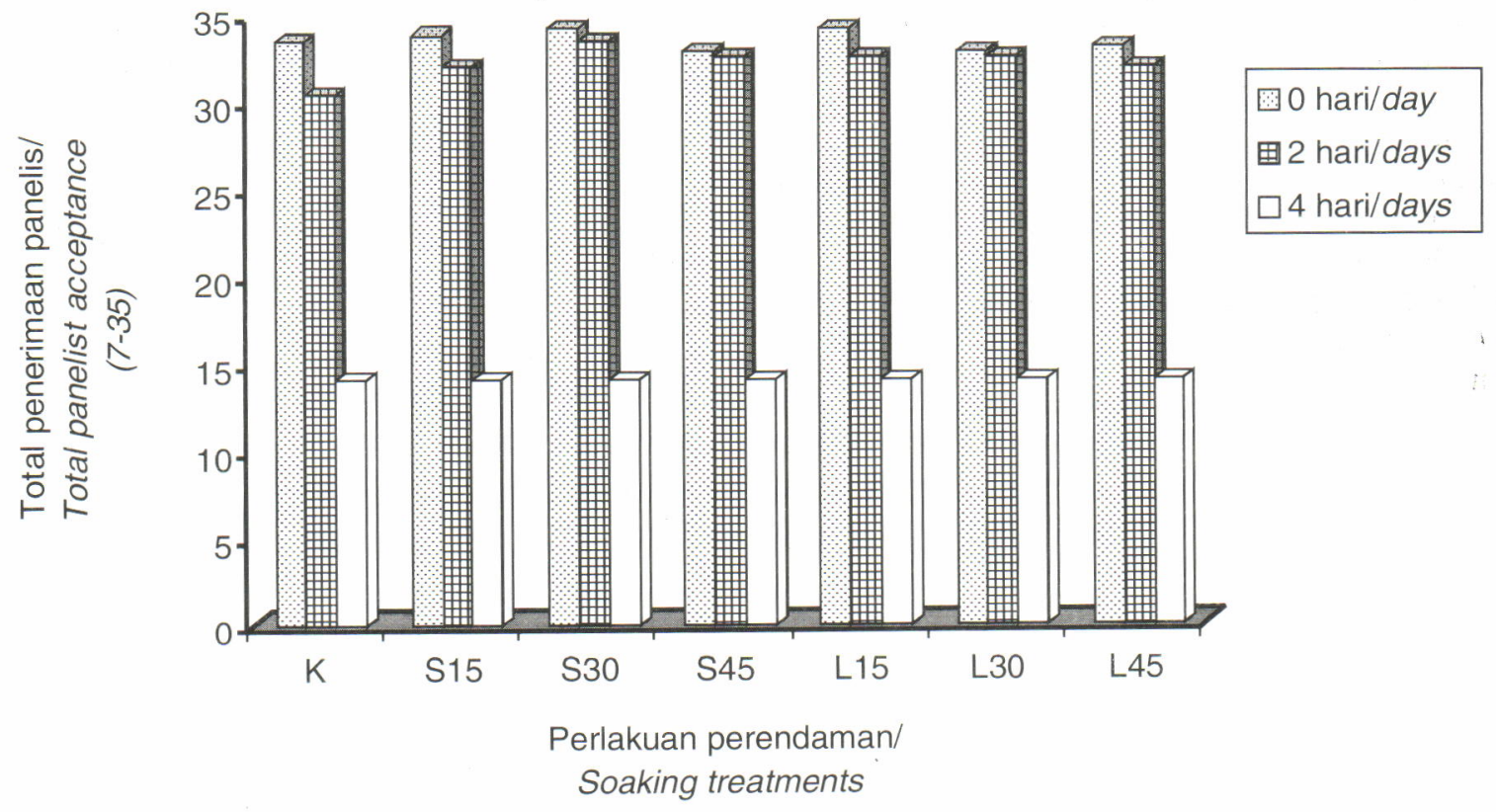

Keterangan/Note: $\mathrm{K}=\mathrm{Kontrol} /$ Control

$\mathrm{S}=$ As.Sitrat/Citric Ac. $(15,30,45 \mathrm{menit} / \mathrm{min})$

$\mathrm{L}=$ As. Laktat/Lactic Ac. $(15,30,45 \mathrm{menit} / \mathrm{min})$

Gambar 6. Penerimaan panelis terhadap pindang ikan lisong (S. australasicus CV) dari berbagai perlakuan selama penyimpanan.

Figure 6. $\quad$ Panelist acceptance during storage of treated boiled slimy mackerel (S. australasicus CV) of various treatments.

\section{DAFTAR PUSTAKA}

Ababouch, L., Afilal, M.E, Rhafiri, S., and Busta, FF. 1992. Identification of histamine-producing bacteria isolated from sardine (Scomber pilchards) stored in ice \& ambient temperature. J. Microbiol. 8(2): 127-136.

Anggawati, A.M., Fauzya, Y.N., dan Putro, S. 1984. studies on histamine contents of cured fishery product. Laporan Penelitian Teknologi Perikanan. 33: 29-32.

AOAC. 1980. Official Methods of Analysis, $13^{\text {th }}$ ed. Association Official of Analytical Chemist. Washington DC. $1018 \mathrm{pp}$.

Beirão, L.H. 1979. Parametros de avaliancao de sardinha (Sardinella brasiliensis) no processo de anchovagem. Campinas: UNICAMP/FCA. 110 pp.

Bennour, M., Marrakchi, A.E., Bouchriti, N., Hamama, A. and Ouadaa, M.E. 1991. Chemical and microbiological assessments of mackerel (Scomber scombrus) stored in ice. J. Food. Prot. 54: 789-792.

Connel, J.J. 1975. Control of Fish Quality. Surrey: Fishing News. 177 pp.

Den Uijl, C.H. 1989. The Preserving Effect of Lactic Acid and Lactates. CCA biochem b.v. Gorinchem, Holland. $24 \mathrm{pp}$.
Fardiaz, S. 1992. Mikrobiologi Pengolahan Pangan Lanjut. Pusat Antar Universitas Pangan dan Gizi. Institut Pertanian Bogor. 283 pp.

Haaland, H., Arnesen, E., and Njaa, L.R. 1990. Amino acid composition of whole mackerel (Scomber scombrus) stored anaerobically at $20^{\circ} \mathrm{C}$ and at $2^{\circ} \mathrm{C}$. Int. J. Food. Sci. Technol. 25: 82-87.

Hardy, R and Smith, J.G.M. 1976. The storage of mackerel (Scomber scombrus). Development of histamine \& rancidity. J. Food. Sci. 27: 595-599.

Hernandez-Herrero, M.M., Roig-Sagues, A.X., LopezSabater, E.I., Rodriguez-Jerez, J.J. and Mora-Ventura, M.T. 1999. Total volatile bases nitrogen and other phsyco-chemical and microbiological characteristics as related to ripening of salted-Anchovies. J. Food Sci. 64(2): 344-347.

Heruwati, E.S., Murtini, J.T., Indriati, N., Ariyani, F.,Dwiyitno, Subaryono dan Suryanti. 2003. Riset Keamanan Pangan Produk Perikanan Selama Penanganan dan Pengolahan. Laporan Teknis Bagian Proyek Riset Pengolahan Produk dan Sosial Ekonomi Kelautan dan Perikanan T.A. 2003.

Kongpun, O. and Suwonsakornkul, P. 2000. Histamine formation during salting of spanish mackerel (Scomberomorus commerson). J. Aq. Food Prod. Technol. 9(1): 21-30. 
Ozogul, F., Polat, A. and Ozogul, Y. 2004. The effect of modified atmosphere packaging and vacuum packaging on chemical, sensory and microbiological changes of sardines (Sardinella pilchardus). $J$. Food Chem. 85(1): 49-57.

Rawies, D.D, Flick G.J. and Martin. 1996. Biogenic amines in fish shellfish. Adv. Food. Nutr. Res. 39: 329-364.

SNI 01-2360. 1991. Pengujian Kimia Produk Perikanan. Penentuan Kadar Histamin. Standar Nasional Indonesia.
Steel, R.G.D. and Torrie, J.H. 1989. Prinsip dan Prosedur Statistika, $2^{\text {nd }}$ ed. PT. Gramedia, Jakarta. 748 pp.

Supraptini. 1998. Penelitian tentang cara pengolahan ikan (tongkol, udang, kembung) yang aman untuk kesehatan. Tempo Interaktif, 28 September 2000. www.tempointeraktif.com

Taylor, S.L. 1986. Histamine Poisoning Associated with Fish, Cheese and Other Foods. World Health Organization. VPH/FOS/85.1

Wonggo, J. 1995. Pengaruh Perendaman Filet Ikan dalam Air Kelapa terhadap Kandungan Histamin. Tesis. Program pascasarjana. KPK IPB-UNSRAT. 64 pp. 